\title{
MUTU SABUN MANGKOKAN (Nothopanax scutellaium Merr)
}

\author{
G. R. Hanum ${ }^{1)}$ dan S. Ardiansyah ${ }^{2)}$ \\ Program Studi Analis Kesehatan, Fakultas Ilmu Kesehatan \\ Universitas Muhammadiyah Sidoarjo \\ galuhratmanahanum@ymail.com \\ syahrulardiansyah@umsida.ac.id
}

\begin{abstract}
Mangkokan soap (Nothopanax Scutellaium Merr) is made from extract of mangkokan leaf and the material making of soap there are oil, $\mathrm{NaOH}$, alcohol and glycerin. This research is to find out the quality of microbiology and chemical soap of mangkokan leaf extract (Nothopanax Scutellaium Merr) with 90\% concentration of mangkokan leaf extract . This research is an experimental research with descriptive of data analysis. The results of this study were microbiological quality of Mangkokan extract soap(Nothopanax Scutellaium Merr) has antibacterial activity to Escherichia coli bacteria and there is no microbial contamination. Chemical quality of Mangkokan Extract Soap (Nothopanax Scutellaium Merr) was tested on free alkali level test $0 \%, \mathrm{pH}$ value 11,03 and water content value $0,4668 \%$.
\end{abstract}

Keywords: Escherichia coli, Mangkokan Leaf, Soap.

\section{PENDAHULUAN}

Indonesia adalah negara tropis yang mempunyai beranekaragam tanaman dan tersebar di beberapa daerah, salah satu tanaman tropis yaitu mangkokan (Nothopanax Scutellaium Merr.). Tanaman mangkokan memiliki beberapa manfaat antara lain mencegah rambut rontok, mengobati luka, antibakteri, memperlancar peredaan darah dan antioksidan tubuh.

\section{MATERI}

Flavonoid pada tanaman mangkokan (Nothopanax Scutellaium Merr.) berfungsi untuk anti bakteri, anti oksidan dan anti serangga, (Faridatussadah, 2016).
Senyawa yang terdapat pada tanaman mangkokan seperti flavonoid, alkaloid, saponin (Sudarsono, 2011).

Sabun mandi merupakan sediaan pembersih kulit yang dibuat dari bahan pembuat sabun yaitu minyak, $\mathrm{NaOH}$, alkohol dan gliserin. Pembuatan sabun dapat dilakukan melalui proses saponifikasi dan netralisasi.
Pembuatan sabun dapat
dilakukan melalui proses
saponifikasi dan netralisasi. Reaksi
saponifikasi dengan mereaksikan
asam lemak atau minyak dengan
larutan alkali pada suhu $80^{\circ} \mathrm{C}$ 
sedangkan reaksi netralisasi adalah reaksi untuk memisahkan asam lemak bebas dengan basa atau pereaksi lainnya sehingga membentuk sabun (Anggraini D, 2012). Pada penelitian Galuh (2017), konsentrasi daun mangkokan yang berbeda-beda $70 \%, 80 \%$ dan $90 \%$ tidak terdapat pengaruh yang signifikan terhadap daya hambat bakteri Staphylococcus

\section{METODE PENELITIAN}

Penelitian ini merupakan penelitian eksperimental dengan analisa data secara deskriptif. Mutu mikrobiologi dengan menganalisa daya hambat minimum dan Total Plate Count (TPC). Sedangkan mutu kimia dengan menganalisa $\mathrm{pH}$, kadar air, uji alkali bebas dan asam lemak bebas

Pembuatan Sabun Daun Mangkokan dengan menimbang 35 gram minyak kelapa, 10 gram $\mathrm{NaOH}$ dan 25 Alkohol 96\% lalu dipanaskan dan diaduk perlahan hingga homogen kemudian ditambahkan ekstrak daun mangkokan. Kemudian, dicetak dan didiamkan selama 24 jam.

Penentuan konsentrasi hambat minimum dilakukan dengan metode dilusi agar pada sabun mangkokan dengan konsentrasi 90\%. Sebanyak $0.525 \mathrm{~g}$ serbuk Mueller Hinton dilarutkan dalam $25 \mathrm{ml}$ aquadest. Media Nutrient Agar dimasukkan ke dalam cawan petri sebanyak 15 $\mathrm{ml}$ dan dibiarkan memadat pada suhu kamar. Menyiapkan bakteri E.Coli disiapkan sebanyak $0,2 \mathrm{ml}$ aureus. Sabun mampu menghambat pertumbuhan bakteri gram positif maupun gram negatif.

Escherichia coli salah satu bakteri yang banyak ditemukan di dalam usus besar manusia dan sebagai flora normal. Bakteri Escherichia coli dapat menyebabkan infeksi pada usus dan menimbulkan infeksi pada jaringan tubuh lain di luar usus (Jawetz, 2012).

lalu disebar diatas permukaan Nutrient Agar lalu diinkubasi selama 24 jam pada suhu $37^{\circ} \mathrm{C}$. Kemudian diamati adanya pertumbuhan koloni bakteri atau tidak. Konsentrasi terendah dari antibakteri yang tidak terjadi pertumbuhan bakteri pada cawan petri merupakan konsentrasi hambat minimum (KHM). Larutan kontrol positif digunakan larutan kloramfenikol 30 IU. Sedangkan untuk kontrol negatif adalah media agar dasar tanpa ekstrak daun mangkokan.

Uji Alkali Bebas dan Asam Lemak Bebas dengan cara Sebanyak 14 gram sampel ditimbang dan dimasukkan ke dalam Erlenmeyer $250 \mathrm{~mL}$ yang telah diketahui berat kosongnya. Kemudian ditambahkan $25 \mathrm{~mL}$ etanol 95\%, lalu dipanaskan pada suhu $40^{\circ} \mathrm{C}$. Ditambahkan $2 \mathrm{~mL}$ indikator fenolftalein. Setelah itu, dititrasi dengan $\mathrm{NaOH} \quad 0,05 \quad \mathrm{M}$ sampai terbentuk larutan yang berwarna merah muda dan tidak hilang selama 30 detik. Volume 
$\mathrm{NaOH}$ yang digunakan dicatat dan dilakukan perhitungan

\section{PEMBAHASAN}

Pada pembuatan sabun ekstrak mangkokan

(Nothopanax

Scutellaium Merr, menambahkan gliserin yang berperan sebagai humektan dapat meningkatkan transparansi dan sebagai pelembut. Pencampuran $\mathrm{NaOH}$ dilakukan setelah larutan homogen dan $\mathrm{NaOH}$ berfungsi sebagai bahan pembuat sabun.

Kulit normal pada manusia memiliki pH sekitar 5. Ketika menggunakan sabun, $\mathrm{pH}$ akan meningkat untuk sementara dan kenaikan $\mathrm{pH}$ pada kulit tidak akan melebihi pH 7 (Jellinek, 1970). Nilai $\mathrm{pH}$ pada sabun mangkokan (Nothopanax Scutellaium Merr) adalah 11,03. Reagen ester natrium akan mengalami hidrolisis dengan asam lemak sehingga alkali bebas yang terdapat pada sabun dapat meningkatnya $\mathrm{pH}$ sabun (Nurhadi, 2012).

\begin{tabular}{lcr}
\multicolumn{1}{c}{ Banyaknya } & air & yang \\
ditambahkan & pada & sabun \\
mangkokan & \multicolumn{2}{c}{ (Nothopanax } \\
Scutellaium & Merr) & akan \\
mempengaruhi & kelarutan & sabun
\end{tabular}
dalam air, sehingga sabun akan mudah menyusut apabila digunakan. Pada konsentrasi ekstrak mangkokan (Nothopanax Scutellaium Merr) 90\% nilai kadar air sebesar 0,4668\% dan hasil ini sesuai SNI 06-3532-1994 yaitu tidak boleh lebih dari 15\%. Kadar air yang rendah pada sabun ekstrak mangkokan

(Nothopanax Scutellaium Merr) mengindikasikan daya simpan yang relatif lebih lama.

Total asam lemak adalah jumlah keseluruhan dari asam lemak pada sabun yang telah bereaksi dengan alkali. Pada pengujian kadar alkali bebas menunjukan hasil yang cukup memuaskan yaitu $0 \%$, hal ini menandakan bahwa pada setiap formula sabun tidak memiliki alkali atau basa yang bersifat bebas. Sesuai persyaratan SNI 06-35321994 kadar alkali bebas pada sabun kurang dari $0,1 \%$. Kadar alkali bebas pada sabun ekstrak mangkokan (Nothopanax Scutellaium Merr) yang rendah karena seluruh basa yang digunakan telah berikatan dengan fase minyak saat pembuatan sabun dan tidak mengakibatkan iritasi pada kulit.

Pada konsentrasi ekstrak mangkokan (Nothopanax Scutellaium Merr) $90 \%$ hasil pengujian konsentrasi hambat minimum sebesar 0,656 dan memiliki daya hambat terhadap pertumbuhan bakteri Escherichia coli yang lemah, menurut Davis dan Stout (1971) bahwa diameter zona hambatan dibagi menjadi 3 kategori yaitu, daya hambat sebesar $20 \mathrm{~mm}$ atau lebih dikategorikan sangat kuat, daya hambat10-20 $\mathrm{mm}$ dikategorikan kuat, daya hambat 5$10 \mathrm{~mm}$ dikategorikan sedang dan 
daya hambat $5 \mathrm{~mm}$ atau kurang dikategorikan lemah.

Pengujian Total Plate Count (TPC) mikroba dilakukan dengan alat Colony Meter. Dilakukan 3 kali pengujian agar dihasilkan data yang akurat. Pada penelitian ini, tidak didapatkan mikroba pada sabun ekstrak mangkokan (Nothopanax Scutellaium Merr) hal ini dapat

\section{KESIMPULAN}

Mutu mikrobiologi Sabun Ekstrak Mangkokan (Nothopanax Scutellaium Merr) memiliki aktivitas antibakteri terhadap bakteri Escherichia coli dan tidak terdapat pencemaran mikroba. Mutu kimia

\section{SARAN}

Sabun Ekstrak Mangkokan (Nothopanax Scutellaium Merr) dapat diujikan secara in vivo pada

\section{DAFTAR PUSTAKA}

Anggraini D, Wiwik SR, Masril M. 2012. Formulasi Sabun Cair dari Ekstrak Batang Nanas (Ananascomosus. L) untuk Mengatasi Jamur Candida albicans. Jurnal Penelitian Farmasi Indonesia 1(1), September 2012.

Bibiana. 1994. Analisis Mikrobiologi di

Laboratorium. Jakarta : Raja Grafindo Persada.

$\begin{array}{cr}\text { Budiyanto, A.K. } & 2004 . \\ \text { Mikrobiologi } & \text { Terapan. } \\ \text { Malang : } & \text { Universitas } \\ \text { Muhammadiyah. } & \end{array}$

diartikan tidak terdapat pencemaran mikroba. Selain ekstrak daun mangkokan (Nothopanax Scutellaium Merr) bahan-bahan sabun juga bersifat antiseptik dan antimikroba. Alkohol memiliki sifat antiseptik hal ini karena alkohol mampu mendenaturasi protein dan melarutkan lemak.

Sabun Ekstrak Mangkokan (Nothopanax Scutellaium Merr) pada pengujian kadar alkali bebas sebesar $0 \%$, Nilai $\mathrm{pH}$ sebesar 11,03 dan nilai kadar air sebesar $0,4668 \%$.

hewan coba sebelum diproduksi dan dipasarkan.

Faridatussadah, Siti. 2016. Isolasi dan identifikasi Senyawa Flavonoid dari Daun Mangkokan (Polyscias scutellarium (Burm.f.) Fosb). Jurnal Farmasi. Vol 2. No1.

Hariana, H. A. 2008. Tumbuhan obat dan Khasiatnya. Seri 2. Cetakan 5 : Penebar Swadaya, Jakarta

Jawetz, E., J.L. Melnick., E.A. Adelberg., G.F. Brooks., J.S. Butel., dan L.N. Ornston. 1995. Mikrobiologi Kedokteran. Edisi ke-20 (Alih bahasa : Nugroho \& R.F.Maulany). Jakarta : 
Penerbit Buku Kedokteran EGC. hal. 211,213,215.

Jellinek, S. 1970. Formulation and Function of Cosmetics. Transleted. Wiley

Interscience. New York.

Luis, Lely Sari. 2003. Sabun Obat.USU Digital Library.

Sa'diah, Siti. 2015. Efektivitas Sediaan Emulsi Ekstrak Etanol $70 \quad \% \quad$ Daun Mangkokan (Northopanax Scutellarius(Burm.F)Merr) Sebagai Perangsang Pertumbuhan Rambut.

Fitofarmaka,Vol.4,No.1

SNI 06 - 3532 - 1994. Standar Mutu Sabun Mandi. Dewan Standarisasi Nasional, Jakarta.

Spitz, L. 1996. Soap and Detergent a Theoritical and Practical Review. AOCS Press. ChampaignIllinois.
Susilorini, Tri Eko, Manik Eirry Sawitri. 2006. Produk Olahan Susu. Jakarta : Penebar Swadaya.

Sudarsono, A. The Advantage Medical Plant Mangkokan (Notophanax scutellarium Merr). [dipublikasikan 20 November 2011]. http// www.titan-medicalplant. blogspot.com.

Sudarmadji, Slamet. 2003. Analisa Bahan Makanan Dan Pertanian. Yogyakarta : Liberty.

Suryani. 2014. Uji Aktivitas Tabir Surya Formula Sediaan Losio Ekstrak Metanol Daun Mangkokan (Nothophanax Scutellarium Merr.). Medula Vol. 2 No. 1 